\title{
Out of the Unknown and into the Limelight: The Case of Estonian Russian Literature ${ }^{1}$
}

\author{
ANNELI KÕVAMEES
}

\begin{abstract}
In the era of hyphenated identities, one's identity may not be as clear as decades before; the same applies to culture and literature. Over the past years, there have been discussions about the exact definition of national literature. In Estonia there have been debates surrounding the definition of Estonian literature: is it a literature written in Estonian or is it a literature written in Estonia? One of the most interesting literary debates erupted in connection with the Estonian Russian writer Andrei Ivanov (born 1971), whose novels in many cases have been written in Russian but published first in Estonian. The first part of the article deals with the definition of Estonian literature and the position of the Estonian Russian-language literature. It may be noteworthy that only at the beginning of the $21^{\text {st }}$ century did Estonian literary criticism start to deal with the Estonian Russian-language literature as part of Estonian literature. The authors of the younger generation (born in 1970 and later) or the so-called noughts-generation are the first credibly taken authors as part of Estonian literature. The position of Estonian Russian literature has shifted from rejection and periphery to the spotlight. The works by Andrei Ivanov have played an important role in that process. The second part of the article analyses the depiction of Estonian Russians in Ivanov's A Handful of Dust and Ashes using the branch of comparative literature called imagology or image studies. The Estonian Russian background proves to be a useful tool for creating a character who is alienated, who is an existential outsider. The author deals with existential questions and depicts tendencies in the $21^{\text {st }}$ century society. As many other Estonian Russian writers, Ivanov does not deal specifically with the issues of Estonian Russians and that is one of the reasons of his popularity and one of the reasons why Estonian Russian literature has attracted so much attention.
\end{abstract}

Keywords: Estonian Russian literature, Andrei Ivanov, Estonian Russians, image studies

1 This article is written within the framework of the project no. IUT18-4 Estonia between East and West: The Paradigm of the Images of "Own", "Other", "Strange", "Enemy" in Estonian Cultures at the End of the $19^{\text {th }}$ and in the $20^{\text {th }}$ Century. The article is an expanded version of the article "“A Handful of Dust": the Case of Estonian Russians and Existential Outsiderness" (Kõvamees 2014).

DOI: http://dx.doi.org/10.12697/IL.2015.20.1.7 


\section{Introduction: Defining National Literature}

We live in the globalized world where everything travels: people, ideas, goods; it is possible to be at the other end of the world within hours, "nowhere is remote anymore" (Blanton 2002: 29). Travel has "become a metaphor for the postmodern condition, where conceptual boundaries are blurred" (Roberson 2001: xxi). Over the last decades, exact definitions have started to blur in various fields, for instance, strict gender roles have started to shift. The demographic situation has changed; one can find various nationalities in the world metropolises. The shift from monocultural and monolingual world to multicultural and multilingual one is clearly visible in the modern era. People travel more and live in different countries, in the era of hyphenated identities (e.g. British Asian, African American, etc.) (Thompson 2011:5) one's national identity may not be as clear as before.

The same applies to the definition of national literature. In the era of hyphenated identities where the relationship between foreign and own is shifting, the exact definition of national literature is also under question. For instance, in the last few years there have been discussions about the exact definition of Estonian literature. Is it a literature written in Estonian or is it a literature written in Estonia? Does Estonian literature include Baltic-German literature and what about the Estonian Russian-language literature? One of the main researchers of Estonian Russian literature Igor Kotjuh has asked: "To whom belongs the Estonian Russian-language literature? It does not suit Estonian culture because of the language, nor does it suit Russian literature and culture because it is a local Estonian matter" (Kotjuh 2013b). ${ }^{2}$ It may be concluded that there are two main ways to define Estonian literature: the narrower definition is literature written in Estonian and the broader definition of Estonian literature is literature written in Estonia. The inclusion of Baltic German literature into Estonian literature is just taking place and it is not yet self-evident to take works written in German by compatriots as part of Estonian literature (Helme 2010). The same applies to Estonian Russian literature, which has only started to be considered part of Estonian literature.

Only at the beginning of the $21^{\text {st }}$ century has the Estonian literary criticism started to deal with the Estonian Russian-language literature as part of Estonian literature (Kotjuh 2010: 134). The boundaries have expanded; Estonian literature is not exclusively literature written by Estonian authors in Estonian but includes also Estonian Russian literature. The authors of the younger generation of Estonian Russian writers who emerged after the turn of the century are

\footnotetext{
2 All translations are the author's.
} 
Out of the Unknown and into the Limelight: The Case of Estonian Russian Literature

the first generation of such writers seen as intrinsically part of Estonian literature (Kotjuh 2013a: 68). The generation consists of authors born in the 1970s and 1980s who made their debut in literature in the 2000s, e.g. P. I. Filimonov (born in 1975), Denis Kuzmin (born in 1981), Igor Kotjuh (born in 1978) and Andrei Ivanov (born in 1971) (Kotjuh 2013a: 67). The 2000s saw the principally new Estonian Russian literature created by the noughts-generation. They are characterised by the following characteristics: they identified themselves with Estonia (most of them also speak Estonian) and managed to make contacts with the Estonian-language writers, journalists and editors; they published their Russian language works in the internet and searched for publication possibilities in Estonia; they took care that their works were published in Estonian translation (Kotjuh 2013a: 67). The Russian speaking authors of Estonia have always defined themselves as multicultural (Kotjuh 2013a: 74) but "the reigning socialhistorical paradigm defines a person according to a single national-cultural identity" (Kotjuh 2013a: 79). Because of strict divisions, some works of Estonian Russian authors might remain invisible; they fall between two stools (Laanes 2012), as was the case with Peotäis põrmu (A Handful of Dust) by Andrei Ivanov.

\section{The Case of Estonian Russian Writer Andrei Ivanov}

Andrei Ivanov is an author who may be characterised by his multicultural background: he is a Russian who was born in 1971 in Estonia and spent many years living in Scandinavia. His prose has been published in book form and in literary magazines in Estonia, Russia and USA. He is best known as the author of the novel Путешествие Ханумана на \олланд (A Journey of Hanuman on Lolland) which was nominated for the Russian Booker Prize in 2010 and won the Estonian Cultural Endowment literary price for the Russian language author in 2009. Копенгага (Copenhagen) won the same price in 2011 and Харбинские мотыльки (Harbin Moths) in 2013. Путешествие Ханумана на Аолланд, Зола (Ashes), Мой датский дядюика (My Danish Uncle), Харбинские мотыльки, Бизар (Bizarre), Горсть праха (A Handful of Dust) and Исповедь мунатика (Confession of a Lunatic) have been translated into Estonian. ${ }^{3}$

When the literary panel of the annual awards of the Estonian Cultural Endowment did not nominate Ivanov's novel Peotäis põrmu, literary debate erupted. The novel was written in Russian but had not been published in Russian until 2014 (Belobrovtseva, Meimre 2015: 16); it was published in Estonian in 2011.

3 About Andrei Ivanov and his works, see also Estonian Literature Centre webpage http://www.estlit.ee/elis/?cmd=writer\&id=55407\&grp=1. 
The participants of the debate had different views on how to define Estonian literature. The chairman of the literary panel of the annual awards of the Cultural Endowment stated: “Estonian literature with a capital 'E' falls into Estonian literature and Estonian Russian literature. The first is written in Estonian and the second in Russian, for the first the Cultural Endowment has Estonian literature awards and for the second the award for the author writing in Russian. This is also the way the Institute of the Estonian Language and Estonian Literary Studies deal with the difference” (Lotman 2012).

The head of the cultural office of the Estonian newspaper Eesti Päevaleht, Mari Peegel, on the other hand suggested that maybe the definition of Estonian literature could be also 'literature written in Estonia' (Peegel 2012), so instead of strict divisions the definition should be broader. Estonian literary researcher Eneken Laanes has seen Ivanov's novel as an example of transnational literature. The demographic developments in the last half century have turned not only the western but also all world metropolises into places where people of different national origins live. These people have started to write about their life experiences of living on the cultural borders. They often write in the local language, but not always; bilingualism or multilingualism are not rare. The characters of Andrei Ivanov's novel Peotäis põrmu also live on cultural borders and as such they have attracted the attention and approval of Estonian readers (Laanes 2012).

Peotäis põrmu gives an insight into the world of Estonian Russians who form the biggest national minority in Estonia. In the following, the depiction of Estonian Russians in Ivanov's Peotäis põrmu and Tuhk (Ashes) is under observation using the branch of comparative literature called imagology or image studies, which deals with the research of national images and stereotypes and their manifestation in literature. There are two main terms: auto-image (or self-image) and hetero-image: the first refers to "a characterological reputation current within and shared by a group, the latter to the opinion that others have about a group's purported character"4 (Leerssen 2007: 342-343). Imagology provides a helpful tool when studying various images and constructions of identity.

\section{Becoming an Alien and Alienation}

Ivanov's Tuhk gives an insight into the 1990s, which saw great changes in the society: after the disintegration of the Soviet Union, Russians living in Estonia

4 For example, "Thomas Mann writing, as a German, about German culture expresses a German auto-image; Madame de Staël's De l'Allemagne expresses an outside view or hetero-image" (Leerssen 2007: 343). 
Out of the Unknown and into the Limelight: The Case of Estonian Russian Literature

found themselves in a situation where they were just a Russian minority in the independent Republic of Estonia. Historically Estonia had always had a Russian minority but never before had it been as large as after the collapse of the Soviet Union. "The post-Soviet Russian diaspora in the Baltic countries was novel not only in and of itself, but in comparison with other communities in the post-colonial world. [...] [T] he transformation of a group from the status of linguistic and cultural dominance to one of a minority occurred without a change of residence. This is most unusual in traditional diasporas" (Laukkonen 2012: 24). The Russians living in Estonia had three choices: to become a citizen of the Russian Federation or a citizen of the Republic of Estonia or to leave one's citizenship unidentified and take the alien's passport or the so-called grey passport (named after the colour of the latter). ${ }^{5}$

The changes in the society and their influence on people are under observation in Ivanov's works. In Tuhk the main character clearly senses the change: "The town as a whole started to lose its familiarity. New faces appeared and new customs emerged. [...] Our time started to pass by. [...] The town ceased to be ours. The most expressive evidence of the alienation of one's hometown became the alien's passport, which was given to me among the other "foreigners" like me" (Ivanov 2010: 98). Not only did the value system and institutions collapse but also the place to identify oneself with turned alien (Kurg 2010). Being or not being a citizen is one important component in one's identity construction and it is an important topic among the Russian characters, Russians in Estonia being not merely Russians but they are also citizens or aliens. Therefore, Russians may be seen as doubly strange from the Estonians' viewpoint: they belong to the other group by speaking a different language, having different customs and having a different nationality. In Ivanov's Peotäis porrmu and in Tuhk the Russian characters sense that differentiation clearly. There is a clear distinction between who is a stranger and who is one's own.

"Ashes and A Handful of Dust mostly deal with Tallinn. Or rather a town called Tallinn, which contains familiar places and features, but is not quite the real Tallinn. Something is wrong here, not as it should be. This is especially evident in Ashes, where houses in the street at the edge of the marshland in the Pääsküla area quietly slide down the slope, inch by inch" (Jüristo 2014). Estonia in his books is often seen from an unexpected angle (Ross 2010: 136). The main

Andrei Ivanov, who also has that "grey passport", has said, "Citizenship - unidentified. Where else could you find such a fantastic document? It corresponds superbly to my state of mind" (Afanasjev 2012). The issue of Ivanov's citizenship was raised at the end of 2014 and beginning of 2015 when it was discussed whether Ivanov should be given Estonian citizenship for achievements of special merit. 
character of the novel Peotäis porrmu never really finds his place after returning to his hometown Tallinn after living in Scandinavia. He returns to his hometown and from the beginning feels out of place, he does not recognize Tallinn, everything seems to be out of place like in a distorting mirror. "All the time I had the feeling that I had got off at the wrong station" (Ivanov 2011: 7). The city and his identity are both dislocated. "Everything seemed to have shifted, as if during these seven years when I was ambling from country to country, some crafty illusionists had hanged distorting mirrors everywhere in the town" (Ivanov 2011: 7). He walks the streets and goes to places, meets various people, even marries but he never really connects. He keeps his outsider's look and is always somehow alienated.

"Alienation and being an alien are central themes for Ivanov, running through all his works. His protagonist is never at home anywhere. [...] His relationships fall apart, he feels estranged from old friends, and people in the street cast suspicious glances in his direction, ready to grab their mobile phones from their pockets and make calls where necessary. But he has no way out as "they have divided up the entire world, nowhere to hide any more, firms everywhere, affiliated companies, bureaucrats." There are people everywhere with their own incomprehensible lives and things to do, and Ivanov's protagonist does not fit in" (Jüristo 2014). The main characters of Peotäis põrmu and Tuhk can be seen as existential outsiders: they do not feel at home anywhere. Being a Russian living in Estonia as an alien only strengthens the feeling. The main character of the novel Peotäis porrmu states, "The fact that I am standing amidst familiar decorations does not change a thing. I have not been here for a long time, I am not local" (Ivanov 2011: 100).

\section{The Estonian Russian Way}

The main character of the novel Peotäis põrmu is a Russian living in Estonia, his social circle consists of mainly Russians but he feels he does not want to act as a Russian living in Estonia is supposed to act. "They [the Russians] have to go everywhere, the theatre and church and the stadium... Maybe it is one of the attributes of the Estonian Russians. To appear. To visit. To belong. To express. To nod. To read. To look. To hate. To follow. To celebrate. To express indignation, etc., etc. It is easier to be a Muslim than a Russian in Estonia! There is so much to do! There are so many things to believe! And there are so many things to give up!" (Ivanov 2011: 153).

\footnotetext{
6 The quotation is from Peotäis põrmu (Ivanov 2011: 201).
} 
Out of the Unknown and into the Limelight: The Case of Estonian Russian Literature

The Estonian Russians have a certain image, the way they look, act, where they work and live, they fit a certain mould. One important component of the self-image of the Estonian Russian is that "You have to notice that Russians are being oppressed. If you do not notice it, you are no longer a Russian, because Russians are being oppressed and if you no longer feel being oppressed then you have quietly ceased to be a Russian" (Ivanov 2011: 154). One important component of the Estonian Russian identity is opposition. Being an Estonian Russian means that it is obligatory to curse the Estonian government and the way it treats its people. Volodja, an acquaintance of the main character, illustrates this aspect. He is an example of those Russians who have not adapted to the new society but seem to have got stuck in the old times. "Volodja let too many things slip away. Not only his wife, but also the time, he did not learn the language, did not educate himself, he had nothing to barge into the new carriage with. He had been left under the social Darwinism press" (Ivanov 2011: 49).

The other component of the characteristics considered typical of Estonian Russians is a certain attitude towards native Estonians. Russians in Estonia feel the pressure to learn Estonian, to get the Estonian citizenship. They feel that they have been brushed aside. This same attitude is dealt with in Peotäis põrmu. For example, Perepelkin, an acquaintance from the main character's past, who seems to have succeeded in blending in with the new world: he works in the police, speaks and writes good Estonian, has some ideas how to do business, etc. However, he still does not feel that he belongs to this new world, sensing his inferior position. Perepelkin (in Russian 'perepel' means 'quail') states that Russians in Estonia are nothing but aliens: "We will never be part of the elite! We will not be accepted into their circle, no matter how well we speak their language! We will always be second-rate people only because of our national identity. There is no discrimination, just ignorance. Look how they, carefree, sit and sip their cocktails, celebrate something, while we gossip over our hard life, we - strangers in this life's revelry" (Ivanov 2011: 22). Although Perepelkin has more or less adapted to the new society, he has remained the same. "He has remained entirely himself. He has preserved, like some candies by $\mathrm{Kalev}^{7}$, not only the same taste but also the same cover" (Ivanov 2011: 16). Perepelkin is seen through the eyes of the main character who does not go along with Perepelkin's ideas and view of the world but keeps his distance.

The main character of the novel feels alienated and views everything as an outsider, even when depicting the Russians who have found their place in the new society. The new world has given birth to new kinds of characters and Valeri Ivanovitch is the best example here. Valeri Ivanovitch, a colleague of the main

7 Kalev is the biggest and oldest confectionery company in Estonia. 
KÕVAMEES

character, is an example of a successful Russian. He has fully adapted to the new society, has learned the language, has a good education, or as the main character concludes: "He was from head to toe equipped to live in our state" (Ivanov 2011: 77). The main character views his fellow compatriots ironically.

The world of Estonian Russians is a world where people are practically identical, even before the birth their roles seem to be assigned: one is to become a teller in a bank, the other a policeman, the third a bureaucrat. Eventually, there is even no difference with whom one sleeps (Tigasson 2012). As the main character in Peotäis põrmu states: "What's the difference, whether I am in bed with my own wife or Leonid's wife?" "Anyway, what's the difference, is it me or Leonid? [...] We are almost the same!” (Ivanov 2011: 212). In Tuhk the protagonist marks: "The nastiest thing was that life was as predestined as the route of a tram. Nothing was more boring in the world than the tram I sometimes had to take!" (Ivanov 2010: 72).

\section{Ashes and Dust as Symbols}

Peotäis porrmu (A Handful of Dust), which has a motto from T. S. Eliot's The Waste Land, "I will show you fear in a handful of dust", examines the life possibility in the wasteland during the low tide of the European Union through the eyes of local Russians (Oja 2012). The Russians are united by the Bronze Soldier, a Soviet World War Two memorial in Tallinn, one of the leitmotifs in the novel. The disputes surrounding the relocation of the monument peaked with two nights of rioting in Tallinn in April 2007, known as the Bronze Night. Most of the Russians living in Estonia see it as an act against them, but the main character remains indifferent. Noticeably, the main character's wife gives birth to a stillborn child in the Bronze Night when local Russians expect something to happen but in the end nothing important happens and as a symbol the dead child, ${ }^{8}$ a handful of dust, is buried along with the memories.

Ashes and memories are also bound together in Tuhk (Ashes). The main character lives in Denmark in a crumbling old castle where he works as a stoker;

8 While in Peotäis põrmu a stillborn is born, in Tuhk the main character's child is never born because of the abortion. The child could have been a way to another life: "If I had known, if I had only known that she was pregnant, I would have done everything to save our child. I would have found a job. I would have conjured the passport with all the Estonian language categories. I would have bought the documents proving that I am the best business manager in the world! I would have become the mayor of Tallinn. Whoever!" (Ivanov 2010: 117). However, the child is never born and the life that could have been never turns into a reality. 
Out of the Unknown and into the Limelight: The Case of Estonian Russian Literature

he heats the stoves and shovels out the ashes. He is looking back, recollecting times and people gone by; remembering is like shovelling the ashes out of the stove. Like coal turns into ashes, life passes by and what is left is memories. It has been observed that to deal with his past the protagonist has chosen the path of destroying the memories. Ashes indicate simultaneously the abolition of memories and the disappearance of values, relinquishing all the rest, ashes are the only thing mediating his relationship with the world and other people (Kurg 2010). The main character receives the message of the death of his father whose violent behaviour and drinking eclipsed his childhood. His father is cremated, eventually he is also nothing but a handful of dust. While reading both Peotäis porrmu and Tuhk a phrase from the burial service comes to mind: ashes to ashes, dust to dust, people and memories are both buried, in the end, nothing is left but ashes/dust.

\title{
Conclusion
}

In the multicultural world and in the era of hyphenated identities the definition of national literature is shifting and the inclusion of the Estonian Russianlanguage literature into Estonian literature is one of the signs. Based on the works of Andrei Ivanov it may concluded that the Estonian Russian authors are not specifically Russian or Estonian Russian oriented but they deal with more universal issues, they map the nowadays world. The main characters of Peotäis põrmu and Tuhk can be seen as existential outsiders and being a Russian living in Estonia only strengthens the feeling. The Estonian Russian background proves to be a helpful tool for creating characters who are alienated, thus giving a piercing look into the modern society. Tuhk and Peotäis põrmu reflect the modern society: globalization, alienation, loneliness, depression, people are addicted to antidepressants and feel unable to truly connect with the surrounding life. Dealing with these topical issues can be one of the reasons of the popularity of Estonian Russian authors and one of the reasons why Estonian Russian literature has moved from periphery into the limelight.

\author{
Anneli Kõvamees \\ anneli.kovamees@tlu.ee \\ Tallinna Ülikool \\ Eesti Keele ja Kultuuri Instituut \\ Narva mnt 29 \\ 10120 Tallinn \\ EESTI
}


KÕVAMEES

\section{References}

Afanasjev, V. 2012. Rahvusvahelise kirjanduse kodanik Andrei Ivanov. - Eesti Ekspress, 01.12, http://www.ekspress.ee/archive/print.php?id=65333836 (08.01.2014)

Belobrovtseva, I., Meimre, A. 2015. Kirjutamine kui püsikestev peeglistaadium. - Keel ja Kirjandus, 1, 16-32.

Blanton, C. 2002. Travel Writing. The Self and the World. New York and London: Routledge.

Helme, P. 2010. Võõras või oma? Kuhu ja kellele kuulub Eesti vene kirjandus? - Eesti Ekspress, 21.02, http://ekspress.delfi.ee/news/arvamus/arvamus/peeter-helmevooras-voi-oma-kuhu-ja-kellele-kuulub-eesti-vene-kirjandus.d?id=29307377 (26.04.2014)

Ivanov, A. 2010. Tuhk. - A. Ivanov, Minu Taani onuke. Tuhk. Tallinn: SA Kultuurileht (Loomingu Raamatukogu, 7-8), 47-122.

Ivanov, A. 2011. Peotäis põrmu. Tallinn: Varrak.

Jüristo, T. 2014. Andrei Ivanov and the Anti-hero of Our Time. - Estonian Literary Magazine, 1, http://www.estlit.ee/elis/?cmd=writer\&id=55407\&txt=7061 (22.10.2014)

Kotjuh, I. 2010. Eesti venekeelne kirjandus: kas osa eesti või vene kirjandusest? - Keel ja Kirjandus, 2, 134-139.

Kotjuh, I. 2013a. Eesti venekeelse kirjanduse nullindate põlvkond: vastuvõtt ja tõrked omaks tunnistamisel. - Methis, 11, 64-83.

Kotjuh, I. 2013b. Kellele kuulub Eesti venekeelne kirjandus? - http://www.delfi. ee/news/paevauudised/arvamus/igor-kotjuh-kellele-kuulub-eesti-venekeelnekirjandus.d?id=66071114 (08.01.2014)

Kõvamees, A. 2014. "A Handful of Dust": the Case of Estonian Russians and Existential Outsiderness. - Interlitteraria, 19/1, 193-201.

Kurg, A. 2010. Viimane nõukogude põlvkond eksiilis. - Vikerkaar, 7-8, http:// www.vikerkaar.ee/index1.php?page $=$ Arhiiv\&a_act $=$ article\&a_number $=5136$ (22.10.2014)

Laanes, E. 2012. Andrei Ivanov ja rahvusülene (eestivene) kirjandus. - Sirp, 08.03, http://www.sirp.ee/index.php?option=com_content\&view=article\&id=14278:a ndrei-ivanov-ja-rahvusuelene-eestivenekirjandus \&catid=7:kirjandus $\&$ Itemid $=9$ \&issue $=3384(08.01 .2014)$

Laukkonen, T. 2012. Baltic-Russian literature - writing from nowhere? - Baltic Worlds, http://balticworlds.com/wp-content/uploads/2012/06/tema-uppslag. $\operatorname{pdf}(13.02 .2015)$

Leerssen, J. 2007. Image. - M. Beller, J. Leerssen, eds., Imagology. The Cultural Construction and Literary Representation of National Characters. Amsterdam-New York: Rodopi, 342-344.

Lotman, R. 2012. Milleks õhutada vaenu tühja koha pealt? - Sirp, 02.03, http:// www.sirp.ee/index.php?option=com_content $\&$ view $=$ article\&id=14210:milleksohutada-vaenu-tuehja-koha-pealt \&catid=9: sotsiaalia \&Itemid=13\&issue $=3383$ (08.01.2014) 
Out of the Unknown and into the Limelight: The Case of Estonian Russian Literature

Oja, A. 2012. Elu võimalikkusest ahermaal. - Sirp, 03.02. http://www.sirp.ee/index.php?option $=$ com_content $\&$ view $=$ article $\& i d=13982$ :elu-voimalikkusestahermaal\&catid=7:kirjandus \&Itemid $=9 \&$ issue $=3379(08.01 .2014)$

Peegel, M. 2012. Eesti proosa vene keeles. Miks mitte? - Eesti Päevaleht, 09.02 http:// www.epl.ee/news/arvamus/juhtkiri-eesti-proosa-vene-keeles-miks-mitte.d?id= 63893641 (08.01.2014)

Roberson, S. L. 2001. Defining Travel: An Introduction. - S. L. Roberson, ed., Defining Travel. Diverse Visions. Jackson: University Press of Missisipi, xi-xxvi.

Ross, J. 2010. Kas Andrei Ivanov on eesti kirjanik? - Vikerkaar, 10-11, 134-136.

Thompson, C. 2011. Travel Writing. London: Routledge.

Tigasson, K.-R. 2012. Maa, kus iial imesid ei sünni. - Eesti Päevaleht, 04.02, http://www. epl.ee/news/kultuur/maa-kus-iial-imesid-ei-sunni.d?id=63872464 (08.01.2014) 